\title{
Business Sustainability and Challenges of Climate Change in Nigerian Indigenous Automobile Companies. A case study of Innoson Motors Ltd, Nnewi, Nigeria
}

\author{
Marcus Garvey Orji ${ }^{1}$, Romanus Nduji ${ }^{2}$ \\ ${ }^{1}$ Department of Marketing, Veritas University, Abuja, Nigeria \\ ${ }^{2}$ Department of Business Administration, Veritas University, Abuja, Nigeria \\ orjimarcusgarvey@yahoo.com
}

\begin{abstract}
Business sustainability is one of the most important challenges of our time. Companies are integrating ideas of sustainability in their marketing, corporate communications, and in all their actions. It is for this reason that this study examined Business sustainability and challenges of climate change in Nigerian Indigenous Automobile Companies with particular emphasis on Innoson Motors Nnewi, Nigeria. The study is a survey research and data were collected from both primary and secondary sources. The target population of the study was 258 employees of the company, and the sample size of 157 was obtained using Taro Yamani. The statistical tool used for data analysis was mean, standard deviation, correlation and multiple regression analysis. The findings revealed that there is a positive relationship between sustainable profit, organizational workers, business opportunities and climate change in Innoson Motors, Nnewi Nigeria. The study therefore recommended that Companies should deploy smart technologies, Invest in new, more environmentally conscious technologies such as green data centre as source of cost reduction as well as competitive advantage; also for there to be a meaningful movement towards absolute emission reduction, companies must test the concept of a trade-off between economic performance and environmental responsibility.
\end{abstract}

Keywords

businesssustainability, sustainableprofit; business opportunities, climatechange

\section{Introduction}

Striking a balance between economic growth and social wellbeing has been around us as a political and managerial challenge for over 150 years. Concern for the wise use of natural resources and our planet also emerged many decades ago, with Carson`s (2015) book Silent Spring a landmark. However, with the widespread acceptance of the interconnectedness of these issues, following the 2015 United Nations Rio Earth Summits, sustainable development became one of the most important challenges of our time (Keating,2017). The recent world crises may imply that a strategy focused solely on shareholder value is no longer viable. Following the success of AI Gores`s inconvenient truth, awareness seems to be growing that a change of mindset is needed, both in consumer behaviour and corporate policies. 
Konfrontasi Journal: Culture, Economy and Social Changes, 7 (1) March 2020, 77-90

ISSN: 1410-881X (Print), 2716-2095 (Online)

Marcus Garvey Orji, Romanus Nduji: Business Sustainability and Challenges of Climate Change in Nigerian Indigenous Automobile Companies. A case study of Innoson Motors Ltd, Nnewi, Nigeria DOI: https://doi.org/10.33258/konfrontasi2.v7i1.99

http://www.konfrontasi.net/index.php/konfrontasi2

How can we develop prosperity without compromising the life of future generations, is a pertinent question we must provide answer to. Whether this increased attention to sustainability is in itself sustainable can be debated, but some developments indicate that it is (Hedstrom 2017;Holliday,2019). In the words of Diamond (2015), sustainability means the study of how natural systems function, remain diverse and produce everything it needs for the ecology to remain in balance. It also acknowledges that human civilization takes resources to sustain our modern way of life. Sustainability takes into account how we might live in harmony with the natural world around us, protecting it from damage and destruction. Sustainability and sustainability development focuses on balancing and the needs to protect the environment in which we and others live. According to Davis and Sun (2016), Business sustainability is often defined as managing the triple bottom line - a process by which companies manage their financial, social and environmental risks obligation and opportunities. Those three impacts are sometimes referred to as profit, people and planet.

It is in the light of this that this study intends to examine the issue of business sustainability and challenges of climate change in Nigerian indigenous automobile companies with particular emphasis on Innoson Motor Company Ltd, Nnewi, Nigeria.

\subsection{Statement of the Problem}

In many countries, hurricanes, sandy storms, earthquakes and other disruptive occurrences have threatened lives and survival of both businesses, people and resources (Holliday,2019).. Furthermore, Davis and Sun (2016) have argued that given the ongoing trends in global usage of energy, increased demand for development and global population growth, the world should expect corresponding terrible effects of climate change. As business has been seen as the chief motivator in the rapid global growth and development, it has started to reflect more clearly as the mover in global environmental governance. Investments in managing current business risks from weather, water, and environmental shifts become even more justified in a changing climate. In the case of climate change, it is evident that indigenous firms are earning little or low profit as well as poor business opportunities irrespective of their best efforts. Measures harnessed by these firms to enhance improvement are at a very low ebb thereby creating business failure and poor performance. Prior studies on the subject matter have found a positive relationship between business sustainability and climate change, such as Hedstrom (2017), Holliday,(2019), but none was conducted on indigenous automobile companies in Nigeria such as Innoson Motors Nnewi, hence this study is significant.

On the whole the study will provide answers to the following pertinent questions;

1. What extent does sustainable profit affect climate change in Nigerian indigenous automobile companies, especially Innoson Motors, Nnewi.?

2. Is there any significant effect of organizational workers activities on climate change in Innoson Motors, Nnewi?

3. What is the significance of business opportunities on climate change in Innoson Motors, Nnewi?

\subsection{Hypotheses of the Study}

The following hypothetical assumptions have also been formulated for validation by this study;

1. H01, There is no significant effect of sustainable profit on climate change in Nigerian indigenous automobile companies, especially Innoson Motors, Nnewi? 
2. H02. There is no significant effect of organizational workers activities on climate change in Innoson Motors, Nnewi?

3. H03. There is no significance effect of business opportunities on climate change in Innoson Motors, Nnewi?

\section{Review of Literature}

\subsection{Concept of Business Sustainability}

Sustainability in the context of sustainable development is defined by Davis and Sun (2016) as a form of progress that meet the needs of the present without compromising the ability of future generations to meet their needs. This broad definition emphasizes the aspect of future orientation as a basic element of sustainability. This care for future implies, among other things a wise use of natural resources and other aspects regarding the environmental footprint. The green aspect of sustainability is recognized in many other definitions of sustainability. Other authors emphasize sustainability in relation to the development of underdeveloped regions. For example, Barbier (2018) links sustainable development to increasing the material standard of living of the poor at the grass-root level which can be quantitatively measured in terms of increased food, real income, educational services, healthcare sanitation and water supply, emergency, stocks of food and cash, etc.

The combination of both social and environmental perspectives can be found in the earlier - mentioned report by Davis and Sun (2016).The report states that in its broadest sense, sustainable development strategy aims at promoting harmony among human beings and between human and nature.

Dyllick and Hockets (2014) elaborates on the generic definitions in a definition more focused on sustainable management of organizations. Adopting business strategies and activities that meet the needs of the enterprise and its stakeholders today while protecting, sustaining and enhancing the human and natural care for the environment is the new emphasis. John Elkington (2018), in his book Cannibals with Forks: the triple Bottom line of 21 st Century Business, Identified this as the triple bottom line or Triple-P (People, Planet, social sustainability and environmental sustainability.

According to Davis and Sun (2016), Business sustainability is often defined as managing the triple bottom line - a process by which companies manage their financial, social and environmental risks, obligation and opportunities. Those three impacts are sometimes referred to as profit people and planet. However this approach relies on an accounting based perspective and does fully capture the time element that is inherent within business sustainability. A more robust definition is that business sustainability represents resiliency over time - businesses that can survive because they are intimately connected to healthy economic social and environmental systems. These businesses create economic value and contribute to healthy ecosystems and strong communities. Business sustainability requires firms to adhere to the principle of sustainable development and environmental accountability (climate change land use, biodiversity). According to Davis and Sun (2016), sustainable development is the development that meets the needs of the present without compromising the ability of the future generations to meet their own needs. So, for industrial development, to be sustainable, it must address important issues at the macro level such as economic efficiency human, rights), etc.

From the literature and definitions mentioned above, three key elements of business sustainability can be identified; 
1. Business Sustainability is about integrating economic

Environmental and social aspects: This element refers to the triple bottom line or three -P concepts as states by Elkington (2015) and acknowledge by Adam (2018) as the three pillars of sustainability: Social, Environmental and Economic. The concept suggests that three dimensions are inter-related and therefore may influence each other in multiple ways.

\section{Business sustainability is about integrating short-term and long-term aspects}

This element focuses attention on the long-term nature of the matter at hand. An important notion in this aspect is that the economic perspective, because of discount rates, tends to value short term effect more than long term effects, whereas social impacts or environmental degradation may not occur before the long term.

\section{Business sustainability is about consuming the income and not the capital}

This idea is common in business. From a social or environmental perspective, however, the impact may not be visible in the short-term, causing degradation of resources in the long run. Sustainability implies that the natural capital remains intact. This means that the sources and sink functions of the environment should not be degraded. Therefore, the extraction of renewable resources should not exceed the rate at which they are renewed, and the absorptive capacity of the environment to assimilate waste, should not be exceeded (Gilbert et al, (2014).

\section{a. Pillars of Business Sustainability}

In 2015, the World Summit on Social Development identified three core areas that contribute to the philosophy and social science of sustainable development. These pillars in many natural standard and certification scheme form the backbone of tackling the core areas that the world now faces. Based on the definition of sustainability above by Diamond (2015), we must consider the future $t$ in making our decisions about the present. The basic pillars are:

1. Economic Development: This is all about providing incentives for business and other organizations to adhere to sustainability guidelines beyond their normal legislative requirements. Also, to encourage and foster incentives for the average person to do their bit where and when they can. The supply and demand market is consumerist in nature and modern life requires a lots of resources every single day for the sake of environment, getting what we consume under control is the paramount issue. Economic development is about giving people what they want without comprising quality of life, especially in the developing world and reducing the financial burden and red tape of doing the right thing.

2. Social Development: There are many facets to this pillar. Most importantly is awareness of and legislation protection of the health of people from pollution and other harmful activities of business and other organizations. In North America, Europe and rest of the developed world, there are strong checks and programme of legislation in place to ensure that people 's health and wellness is strongly protected. It is also about maintaining access to basic resources without compromising the quality of life. The biggest hot topic for many people right now is sustainable housing and how we can better build the house we live from sustainable material. The final element is education - encouraging people to participate in environmental sustainability and teaching them about the effects of environmental protection as well as warning of the dangers if we cannot achieve our goals. 
3. Environmental Protection: This is the third pillar and to many the primary concern of the future of humanity and business activities. It defines how we should study and protect ecosystems air quality, integrity and sustainability of our resources and focusing on the elements that place stress on the environment. It also concerns how technology will drive our greener future. It also recognizes that developing technology and biotechnology is the key to this sustainability, and protecting the environment of the future from potential damage that technological advances could potentially bring.

\section{b. Goals Associated With Business Sustainability}

The sustainable development professional network think, acts and work together globally. In 2012, the United Conference on Sustainable Development (UCSD) met to discuss and develop a set of goals to work towards; they grew out of the millennium Development Goals (MDGs) that claimed success in reducing global poverty while acknowledging there was still much more to do. The Sustainable Development Goal (SDG) eventually came up with a list of, items which included amongst other things:

1. The need eradicate poverty and hunger.

2. Better standard of education and healthcare - particularly as it pertains to water quality and better sanitation.

3. To achieve gender equality

4. Sustainable economic growth while promoting jobs and stronger economies

5. All of the above and more while tackling the effects of climate change, pollution and other environmental factors that can harm and do to harm people`s health, livelihoods and lives.

6. Sustainability to include health of the land, air and sea.

Best Practices to Foster Business Sustainability

According to Davis and Sun (2016), there are a number of best practices that foster business sustainability and help organizations move along the path from laggards to leaders. These practices include:

1. Stakeholder engagement: Organizations can learn from customers, employees and their surrounding community. Engagement is not about pushing out messages, but understanding opposition, finding common ground and involving stakeholders in joint decision making

2. Environmental Systems: These system provide the structures and processes that help embed environmental efficiency into a firm`s culture and mitigate risks. The most widely recognized standard worldwide is ISO 1400, but numerous others industry-specific and country-specific standards exist.

3. Reporting and disclosure: Measurement and control are the head of instituting sustainable practices. Not only can organizations collect and collate the information. They can also be entirely transparent with outsiders. The Global Reporting Initiative (GRI) is one of many examples of well-recognized reporting standards.

4. Life cycle analysis Those organizations wanting to take a large leap forward should systematically analyze the environmental and social impact of the products they use and produce through life cycle analysis which measure more accurately impacts. Firms that are sustainable have been shown to attract and retain employees more easily and experience less financial and reputation risk. These firms are also more innovative and adaptive to their environments. 


\subsection{Concept of Climate Change}

As put in place by United Nations Framework Convention on Climate Change (UNFCCC) (2014), climate change means a change of climate which is attributed directly or indirectly to human activity that alters the composition of the global atmosphere and which is in addition to natural climate variability observed over comparable time period, while climate system deals with the totality of the atmosphere, hydrosphere, biosphere and geosphere and their interactions over a given period of time. In the words of Issa (2015), climate change may be defined as the change in the statistical properties of the climate when considered over long period of time, regardless of the cause. It is a significant and lasting change in the statistical distribution of weather patterns over period ranging from decades to millions of years. Climate change is caused by factors such as biotic process, variations in solar radiations received by earth, plate tectonics and volcanic eruptions. Certain human activities have also been identified as significant causes of recent climate change. The climate change also known as global warning and everything else increasing green house gas level. Venkataraman (2019) argued that the issue of climate change is one of the contemporary issues affecting Nigeria currently. The report of the British risk consultancy has ranked Nigeria sixth among the countries that are most vulnerable to the effects of climate change. In the 2013 index, which rated 193 countries, reported that rising sea level, flooding and other extreme climate related events would threaten the future of the countries that were rated high. In the list of countries that are highly vulnerable to climate change in this present period, Bangladesh topped the list of extreme risk followed by Guinea, Sierra Leone, Haiti, South Sudan, Nigeria, Democratic Republic of Congo, the Philippines and Ethiopia. London and Paris were in the middle while Iceland, Norway and Ireland were the least affected.

\subsection{Concept of Business Profit}

In the words of Eckhardt and Shane (2016), business profit is the amount remaining after expenses have been subtracted from the income of the business within a specified period of time. The period of time could be stated in monthly, quarterly, or annual terms. Types of profit include gross profit, net profit, and retained profit. The first type of business profit is called gross profit, which is the excess of revenue from sales less the amount of direct costs - costs to create the products or prepare them for sale. This is referred to as cost of goods sold. These costs could include the materials purchased to manufacture products, transportation of materials into the production facility, direct labor to produce them, and distribution costs. Hedsrom, Poltorzyck and Stroh (2017) argued that the easiest way to determine cost of goods sold is to start with the value of the beginning inventory, add the amount of purchases during the period in question, and then subtract the value of the ending inventory.Net profit is the difference between gross profit and operating expenses. Operating expenses differ from direct expenses because they are general business expenses that cannot be directly attributed to the products that are being sold. This is sometimes called overhead expense. Operating expenses are expenditures that companies make in performing normal business activities. They are divided into two categories: selling expenses and administrative expenses. These include such things as sales commissions, depreciation expense, rent, management or office personnel salaries, repairs, office supplies, business licenses, and taxes. Business profit is usually discussed in terms of net profit since it is from this type of profit that owners receive their income or stockholders receive dividends.

Retained profit is the surplus profit after the amount is withdrawn by the owner or dividends are paid to stockholders. This amount is added to the owner's equity or net worth of the business. Business profit is important because without it the company might cease to 
exist. Retained profit is important to the growth of the business and can be used for activities like adding a production line, increasing the size or number of facilities, or research and development of new products (Northrop et al,2016).Owners or managers of companies keep track of business profit by completing a profit and loss statement. This financial statement begins with total or gross sales, less any discounts or returns. Then the cost of goods sold is subtracted to determine gross profit. Operating expenses are subtracted from gross profit to show income from operations. From this figure, other revenue, such as dividends, interest, or rent income, is added and other expenses, such as interest and taxes, are subtracted to arrive at net profit. After any owner disbursements or stockholder dividends are subtracted, the remaining amount of the business profit will be retained profit.

\subsection{Climate Change and Business Sustainability}

The link between climate change and sustainable development stems from the fact that climate change is a constraint to development, and sustainable development is a key to capacities for mitigation and adaptation. It follows that strategies for dealing with sustainable development and climate change have many common element so that applying them together creates synergies. It also follows that since dealing with climate change exclusively could be very expensive, bit has to be factored into development agenda ( Pedercini et al ,2018).Climate change and sustainable development are inextricably linked. The impacts of climate change will increase poverty and vulnerability reduce economic productivity, and increase conflict and forced migration (Leichenko\& Silva,2014;Wilkinson,2016).Left unaddressed, climate change will exacerbate nation and business sustainable development challenges at increasing rates (Kedebe\&Nicholls,2016). Wilkinson et al 2016 argue that a mapping of the alignment between the 2030 Agenda for sustainable development, which aims to end poverty and hunger and protect the business environment and the Paris Agreement; which addresses climate change, shows that beyond sustainable development goals (SDG) 13 (which explicitly addresses climate actions)all seventeen SDGs have corresponding actions in the nationally Determined Contributions (NDCs) to the Paris Agreement. Accordingly, the extent of the alignment between these two agendas provides significant opportunities to approach their implementation in an integrated and synergistic manner (Northrop et al,2016).

\section{a. Climate Impact on Employee Performance}

Climate change is also a major problem which occurs due to changes in climate due to global warming caused by high concentration of green house gases like carbon-dioxide, methane, nitrous-oxide, etc. The presence of high concentration of these gases create problems on health of the manpower, working in the organization due to the fact that these gases have high tendency of absorbing ultraviolet radiation coming from sun and creating ecological imbalance in the ecosystem. These ultraviolet radiations are very harmful for the human being. In the summer, different types of disease attack and employees get suffered with absenteeism, low turnover and irritation, reduce productivity. In an academic institution, performance of students is something that they are not concentrating on their studies, feel very sleepy and tired. As climate condition changes dimensions, so it occurs with a new formula.

\section{b. Factors Responsible for Vulnerability to Climate Change}

There are various factors responsible for vulnerability of many countries including Nigeria to climate change. Among those factors are as follows: 
1. Natural susceptibility: The current experiencing climate change by some African countries including Nigeria is partly due to their natural susceptibility to extreme climate system is rotating across the world of which any country that is experiencingit will be ready to take it but should be reading to find solutions.

2. Lack of good development plans: This is another significant factor responsible for vulnerability of a country to climate change. It is not ideal for a country to be waiting till when climate change is experienced before looking for solutions. The government of a country is expected to plan ahead of this event so that it will not generate unbeatable loss to citizens. The reason why some countries are easily vulnerable is because there was no reasonable development plans towards the period it will happen.

3. Low level of Infrastructure: Climate change is natural and no country can avoid it on getting to her turn but climate change will hardly affect a country that has sufficient infrastructure to tackle climate change events such as floods, droughts. landslides and so on. Many countries of the world including Nigeria is vulnerable mainly because the infrastructure needed to tackle climate problem are not sufficiently provided.

4. Weak economic status: A country that is highly rich and buoyant in her economy will make all possible plans to tackle the climate change and the there will be sufficient provision of infrastructures to be used to tackle it .Nigeria and many other countries of the world are highly vulnerable to climate change because of the weak economy where they cannot provide all necessary infrastructures needed to prevent it.

5. Weak governance: Weak governance is another factor responsible for vulnerability of Nigeria and other African countries to climate change. When the political power is in the hand of the responsible governments, all necessary resources and infrastructures needed will be provided in order to make a country safe from being vulnerable to the problem of climate change.

\section{Research Methods}

This study is a survey research, using data collected from both primary and secondary sources. The secondary sources comprise of mainly text books, journals and periodicals, while primary source was descriptive survey questionnaires. The population comprises of 258 employees of the company under study. The sample size was determined using Taro Yamani`s formula that gave the sample size of 157.The researchers added $10 \%$ margin of this sample size to take care of wrongly filled and unrecovered administered questionnaires. Hence, 173 copies of questionnaire were distributed. The study used judgmental sampling and face to face administration of questionnaire, where the researchers selected units to be sampled based on their knowledge and professional judgment as suggested by Orji \&Enobun (2018). Close ended questions were used for the questionnaire to enable faster data compilation and to easily classify the responses of respondents. The questionnaire was designed using the 5-point likert scale format. Data obtained from the questionnaires administered were analyzed using both descriptive and inferential statistics. The descriptive statistics was the use of simple percentage and mean and inferential statistics using linear regression technique. The choice of regression is because it explains the effect and relationship between two or more variables of interest. It shows the predictive strength of the influence of the independent variable on the dependent variable as opined by Orji (2017). Analysis was carried out using SPSSv21 (Statistical Package for Social Sciences). 


\section{Model Specification}

The regression model used for the data analysis is;

$\mathrm{Y}=\mathrm{a}+\beta_{1} \mathrm{X} 1+\beta_{2} \mathrm{X} 2+\beta_{3} \mathrm{X} 3 \ldots+\mathrm{e}$

$\mathrm{Y}=$ climate change

$\mathrm{a}=$ Intercept (value of $\mathrm{Y}$ when $\mathrm{x}_{\mathrm{j}}$ is Zero)

$\beta_{\mathrm{j}}=$ Regression weight attached to the variation $\mathrm{j}(\mathrm{j}=1,2,3)$

$\mathrm{X}_{\mathrm{i}}=$ sustainable profit

$\mathrm{X}_{2}=$ organizational workers

$\mathrm{X}_{3=}$ business opportunities

$\mathrm{C}=$ Error term

\section{Discussion}

\subsection{Analysis and Findings}

Table 1. Description Analysis of Study Variables

\begin{tabular}{|c|c|c|c|c|c|c|c|}
\hline $\begin{array}{l}\text { Questionnaire } \\
\text { Items }\end{array}$ & SD & D & $\mathbf{N}$ & $\mathbf{A}$ & SA & Mean & $\begin{array}{l}\text { Standard } \\
\text { Deviation }\end{array}$ \\
\hline $\begin{array}{l}\text { Does the firm } \\
\text { compute their } \\
\text { gross profit well. }\end{array}$ & $\begin{array}{c}6 \\
(6.12 \%)\end{array}$ & $\begin{array}{c}6 \\
(6.12 \%)\end{array}$ & $\begin{array}{c}8 \\
(8.16 \%)\end{array}$ & $\begin{array}{c}39 \\
(39.80 \%)\end{array}$ & $\begin{array}{c}39 \\
(39.80 \%)\end{array}$ & 4.01 & 1.14 \\
\hline $\begin{array}{l}\text { Has Innoson } \\
\text { motors obtained } \\
\text { Net profit as } \\
\text { supposed }\end{array}$ & $\begin{array}{c}4 \\
(4.08 \%)\end{array}$ & $\begin{array}{c}10 \\
(10.20 \%)\end{array}$ & $\begin{array}{c}12 \\
(12.24 \%)\end{array}$ & $\begin{array}{c}39 \\
(39.80 \%)\end{array}$ & $\begin{array}{c}33 \\
(33.67 \%)\end{array}$ & 3.89 & 1.11 \\
\hline $\begin{array}{l}\text { Innoson Motors } \\
\text { has used retained } \\
\text { profit well }\end{array}$ & $\begin{array}{c}7 \\
(7.14 \%) \\
\end{array}$ & $\begin{array}{c}7 \\
(7.14 \%)\end{array}$ & $\begin{array}{c}17 \\
(17.35 \%)\end{array}$ & $\begin{array}{c}34 \\
(34.69 \%)\end{array}$ & $\begin{array}{c}33 \\
(33.67 \%)\end{array}$ & 3.81 & 1.19 \\
\hline
\end{tabular}

Note: Strongly Disagree=SD, Disagree $=\mathrm{D}$, Undecided=U, Agree $=\mathrm{A}$, Strongly Agree $=\mathrm{SA}$

The above presents the results of descriptive analysis of respondents opinions on sustainable profit in their organization. As indicated on the table, majority of the respondents agreed that the firm compute their gross profit well with the mean of 4.01 and standard deviation of 1.14. In addition, they also agreed that the firm obtained their net profit as supposed. With the mean of 3.89 and standard deviation of 1.11. Also, they agreed that the firm has used retained profit well with the mean of 3.81 and standard deviation of 1.19.

Table 2. Description Analysis of Study Variables

\begin{tabular}{|c|c|c|c|c|c|c|c|}
\hline $\begin{array}{l}\text { Questionnaire } \\
\text { Items }\end{array}$ & SD & D & $\mathbf{N}$ & $\mathbf{A}$ & $\mathbf{S A}$ & Mean & $\begin{array}{l}\text { Standard } \\
\text { Deviation }\end{array}$ \\
\hline $\begin{array}{l}\text { Workers are } \\
\text { putting in their } \\
\text { best to achieve } \\
\text { the organizational } \\
\text { goal irrespective } \\
\text { of the climate } \\
\text { change }\end{array}$ & $\begin{array}{c}5 \\
(5.10 \%)\end{array}$ & $\begin{array}{c}9 \\
(9.18 \%)\end{array}$ & $\begin{array}{c}11 \\
(11.22 \%)\end{array}$ & $\begin{array}{c}43 \\
(43.88 \%)\end{array}$ & $\begin{array}{c}30 \\
(30.61 \%)\end{array}$ & 3.86 & 1.11 \\
\hline $\begin{array}{ll}\text { Workers } & \text { are } \\
\text { following } & \text { the }\end{array}$ & 6 & 10 & 15 & 40 & 27 & 3.73 & 1.15 \\
\hline
\end{tabular}




\begin{tabular}{|l|c|c|c|c|c|c|l|}
\hline $\begin{array}{l}\text { firm procures } \\
\text { thoroughly }\end{array}$ & $(6.12 \%)$ & $(10.20 \%)$ & $(15.31 \%)$ & $(40.82)$ & $(27.55 \%)$ & & \\
\hline $\begin{array}{l}\text { Workers are } \\
\text { relating with each } \\
\text { well to meet the } \\
\text { target of the } \\
\text { organization }\end{array}$ & 7 & 6 & 13 & 40 & 32 & 3.86 & 1.16 \\
\hline
\end{tabular}

Note: Strongly agreed= SD, Disagreed=D, Undecided=U, Agreed=A, Strongly Agreed=SA

The table above present the results of descriptive analysis of respondents opinion on organizational workers and climate change in the firm. The table shows that the majority of the respondents agreed that the workers are putting in their best to achieve the organizational goal irrespective of the climate with the mean of 3.86 and standard deviation of 1.11. In addition, they also agreed that Workers are following the firm procures thoroughly with the mean of 3.73 and standard deviation of 1.15. Also, they agreed that Workers are relating with each well to meet the target of the organization with the mean of 3.86 and standard deviation of 1.16 .

Table 3. Description Analysis of Study Variables

\begin{tabular}{|l|c|c|c|c|c|c|c|}
\hline $\begin{array}{l}\text { Questionnaire } \\
\text { Items }\end{array}$ & SD & D & N & A & SA & Mean & $\begin{array}{l}\text { Standard } \\
\text { Deviation }\end{array}$ \\
\hline $\begin{array}{l}\text { Workers are } \\
\text { putting in their } \\
\text { best to achieve } \\
\text { the organizational } \\
\text { goal irrespective } \\
\text { of the climate } \\
\text { change }\end{array}$ & 5 & 15 & 12 & 39 & 27 & 3.69 & 1.18 \\
\hline $\begin{array}{l}\text { Workers are } \\
\text { following the } \\
\text { firm procures } \\
\text { thoroughly }\end{array}$ & 7 & 4 & 15 & 36 & 36 & 3.92 & 1.15 \\
\hline $\begin{array}{l}\text { Workers are } \\
\text { relating with each } \\
\text { well to meet the } \\
\text { target of the } \\
\text { organization }\end{array}$ & $(8.14 \%)$ & $(4.08 \%)$ & $(15.31 \%)$ & $(36.73)$ & $(36.73)$ & & \\
\hline
\end{tabular}

Note: Strongly agreed= SD, Disagreed=D, Undecided=U, Agreed=A, Strongly Agreed=SA

The table above present the results of descriptive analysis of respondents opinion on Workers are relating with each well to meet the target of the organization. The table shows that the majority of the respondents agreed that Workers are relating with each well to meet the target of the organization with the mean of 3.96 and standard deviation of 1.18. In addition, they also agreed that Workers are relating with each well to meet the target of the organization with the mean of 3.92 and standard deviation of 1.15. Also, they agreed that Workers are relating with each well to meet the target of the organization with the mean of 3.86 and standard deviation of 1.20. 
Table 4. Description Analysis of Study Variables

\begin{tabular}{|c|c|c|c|c|c|c|c|}
\hline $\begin{array}{l}\text { Questionnaire } \\
\text { Items }\end{array}$ & SD & D & $\mathbf{N}$ & A & SA & Mean & $\begin{array}{l}\text { STANDARD } \\
\text { DEVIATION }\end{array}$ \\
\hline $\begin{array}{l}\text { Does the } \\
\text { decision of the } \\
\text { firm reflect on } \\
\text { the way the firm } \\
\text { manages the } \\
\text { climate change }\end{array}$ & $\begin{array}{c}4 \\
(4.08 \%)\end{array}$ & $\begin{array}{c}5 \\
(5.10 \%)\end{array}$ & $\begin{array}{c}14 \\
(14.29 \%)\end{array}$ & $\begin{array}{c}39 \\
(39.80 \%)\end{array}$ & $\begin{array}{c}36 \\
(36.73 \%)\end{array}$ & 4.00 & 1.05 \\
\hline $\begin{array}{l}\text { Workers Are } \\
\text { favored by the } \\
\text { decisions }\end{array}$ & $\begin{array}{c}5 \\
(5.10 \%)\end{array}$ & $\begin{array}{c}8 \\
(8.16 \%)\end{array}$ & $\begin{array}{c}10 \\
(10.20 \%)\end{array}$ & $\begin{array}{c}50 \\
(51.02)\end{array}$ & $\begin{array}{c}25 \\
(25.51)\end{array}$ & 3.84 & 1.06 \\
\hline $\begin{array}{l}\text { The outcome of } \\
\text { the decision } \\
\text { contributes to } \\
\text { the growth of } \\
\text { the } \\
\text { organization. }\end{array}$ & $\begin{array}{c}3 \\
(3.06 \%)\end{array}$ & $\begin{array}{c}11 \\
(11.22 \%)\end{array}$ & $\begin{array}{c}14 \\
(14.29 \%)\end{array}$ & $\begin{array}{c}46 \\
(46.94 \%)\end{array}$ & $\begin{array}{c}24 \\
(24.49 \%)\end{array}$ & 3.79 & 1.04 \\
\hline
\end{tabular}

Note: Strongly agreed= SD, Disagreed=D, Undecided=U, Agreed=A, Strongly Agreed=SA

Table 5. Underneath Explains the Correlation Matrix for the Study Variables

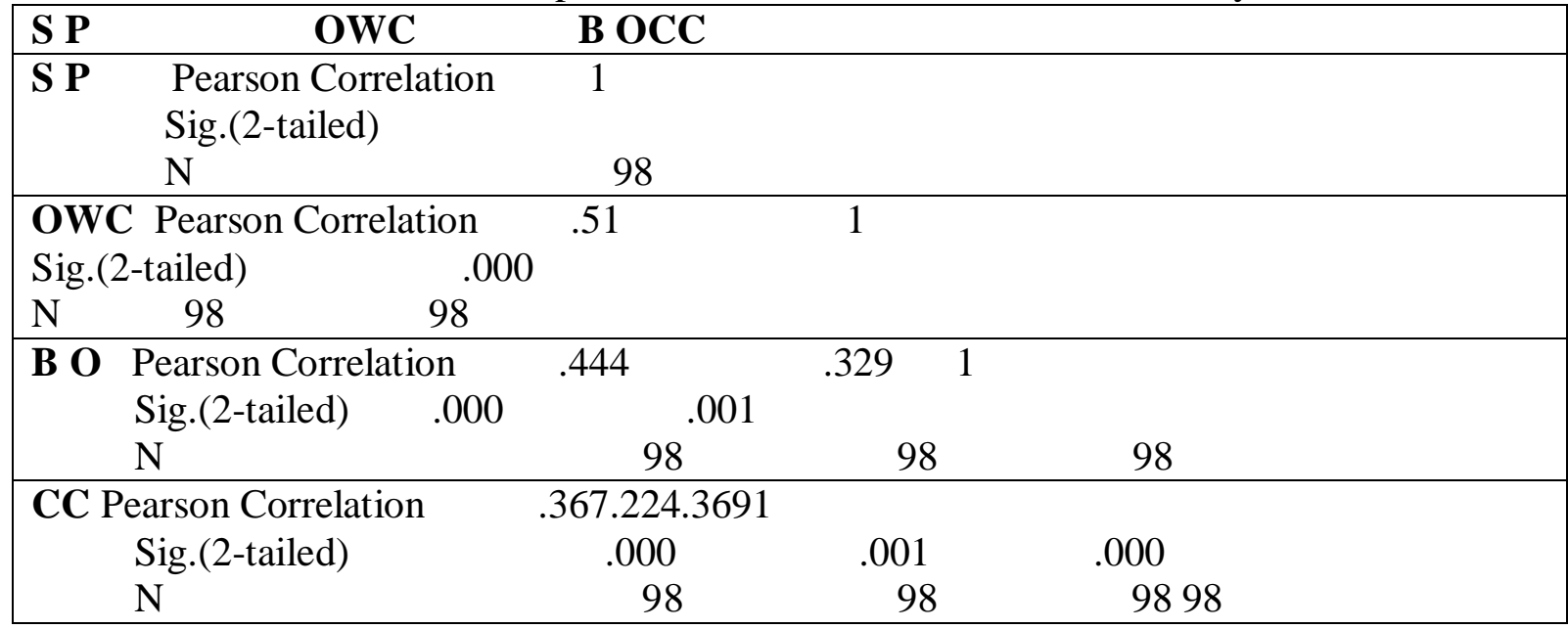

** Correlation is significant at the 0.01 level (2-tailed).

\section{Correlation is significant at the 0.01 level (2-tailed).}

The findings from the research as shown in the above table demonstrate a positive relationship between sustainable profit, organizational workers, business opportunities and climate change in Innoson Motors ,Nnewi. Specifically ,the pearson`s correlation coefficient between climate change and sustainable profitis 0.367 , this means that the two variables move in the same direction. Furthermore, climate change and organizational workers relationship show a pearson`s correlation coefficient of 0.224 .In the correlation matrix table above, there is a strong positive relationship business opportunities and climate change with the pearson`s correlation coefficient of 0.369 
Table 6. Model Summary

\begin{tabular}{|llccc|}
\hline Model & R & R Square & Adjusted R Square & Std. Error of the Estimate \\
\hline I & .858 & .736 & .724 & .42764 \\
\hline
\end{tabular}

a. Predictor (Constant) sustainable profit, organizational workers and business opportunities

The adjusted $\mathrm{R}$ squared is coefficient of determination which indicates the variation in the dependent variable (climate change) due to change in the independent variables. From the data analysis findings in the above table, the value of adjusted $\mathrm{R}$ squared is 0.736 and indicates that there was variation of $73.60 \%$ on climate change due change in sustainable profits, organizational workers and business opportunities at $95 \%$ confidence interval. This shows that $73.60 \%$ o the variations in climate change are accounted or by the variations in the independent variables and the remaining $73.60 \%$ are accounted by other factors not included in the model or standard error. The $\mathrm{R}$ is findings shown in the table above there was a moderate positive relationship between the study variables as shown by 0.858 .

Table 7. ANOVA of Multiple Regressions

\begin{tabular}{|c|c|c|c|c|c|c|}
\hline \multicolumn{2}{|c|}{ Model } & \multicolumn{2}{|c|}{ Sum of Square } & Mean Square & $\mathrm{F}$ & Sig. \\
\hline I & Regression & 47.335 & 4 & 11.834 & 64.708 & .000 \\
\hline & Residual & 17.008 & 93 & .183 & & \\
\hline & Total & 63.343 & 97 & & & \\
\hline
\end{tabular}

a. Dependent Variable: Climate Change

b. Predictor (Constant) sustainable profit, organizational workers and business opportunities

From the ANOVA statistics shown in the table 2 above,the $\mathrm{F}$ critical at $5 \%$ level of significance is 64.708. Since calculated (64.707) is greater than the F critical (2.43).this shows that the overall model was significant. Hence the null hypothesis was rejectedand the conclusion is that sustainable profit, organizational workers and business opportunities significantly affect climate change Innoson Motors Nnewi

Table 8. Coefficient of Multiple Regressions

\begin{tabular}{|lllllll|}
\hline & & \multicolumn{2}{c}{$\begin{array}{c}\text { Unstandardized } \\
\text { Coefficients }\end{array}$} & \multicolumn{2}{c|}{ Standardized } \\
\cline { 5 - 7 } Coefficients \\
Model & B & Std.Error & Beta & \multicolumn{1}{c|}{ S } & Sig. \\
\hline I & (Constant) & .080 & .249 & & .322 & .748 \\
& Sustainable profit & .399 & .076 & .431 & 5.266 & .000 \\
& Organizational workers & .254 & .076 & .244 & 3.901 & .005 \\
\hline
\end{tabular}

a. Dependent Variable: Climate Change

From the above coefficients of multiple regression above, it was revealed that holding the independent variables sustainable profit, organizational workers and business opportunities to a constant zero, climate change in Innoson Motors is 0.080 .

\subsection{Discussion}

The findings of hypothesis one revealed that sustainable profit significantly affect the climate change in Innoson Motors Nnewi. This result could be due to the fact that profit made by the firm are fair ,appropriate and enough ( Davis and Sun (2016).Therefore, null 
hypothesis was rejected. Aslo the result support prior researches conducted by Diamond (2015) who concluded that one of the key ways of making sustainable profit is to ascertain the effect of climate change in an organization.

The results of hypothesis two revealed that there is a positive relationship between organizational workers activities and climate change in Innoson Motors Nnewi. Therefore, the alternate hypothesis and a prior expectation are supported in this study. These results are consistent with the result of studies conducted by scholars examining the influence of organizational workers on climate change in an organization .Keating (2017) confirmed that employment of competent workers can motivate the productivity of the organizational workers.

In respect to hypothesis three, the survey results from this study indicated that there is business opportunity has significance effect on climate change in Innoson Motors Nnewi. This finding is consistent with the previous studies which show that business opportunity affect climate change in any organization (Bartelmus, Peter and Douglas, 2017).

\section{Conclusion}

This study attempted to examine business sustainability and the challenge of climate change in Innoson Motors ,Nnewi Nigeria. The study revealed that business sustainability plays a vital role in Nigeria thereby paving ways to proper control of climate change. The study therefore draw its conclusion on the fact that business sustainability has positive effects on the economic development of Nigeria. Effective business sustainability ensures advancements in all spheres of development in the country as well as standardized economy. With appropriate technological advancements, individual and governmental supports on ground, business sustainability would improve without bounds carrying along economic development, social development and political development.

Based on the findings of the study, the following are the recommendations;

1. Companies should deploy smart technologies, Invest in new, more environmentally conscious technologies such as green data centre as source of cost reduction as well as competitive advantage

2. Also for there to be a meaningful movement towards absolute emission reduction, companies must test the concept of a trade-off between economic performance and environmental responsibility

3. In the course of working for the attainment of the organizational goals, the business management should ensure that their employees are considered thereby ensuring that while the goal is achieved, the welfare of the employees is not adversely affected. With this done, the morale of the employees will not be dampened rather they will put in their best in order to achieve the business sustainability no matter the degree of climate change.

\section{References}

Bartelmus, H. C, Peter, A. I \& Douglas, K. L. (2017).Indicators of Sustainable development. Cutler J. Cleveland (Ed.) Encyclopedia of earth.

Barbier, E. (2018).The concept of sustainable economic development. . Environmental Conversation 14(2):101-110

Carson, R (2016).Silent Spring. Boston: Houghton Mifflin 
Davis, C.H. and Sun, E. (2016).Business development capabilities in information Technology SMEs in a regional economy. An exploratory study: The journal of Technology Transfer, 31(1), 145-161

Dyllick, T. and Hockerts, K. (2014). Beyond the business case for corporate sustainability. Business Strategy and the Environment 11:130-141.

Elkington, J (2018). Cannibals with Forks: The Triple Bottom line of 21st Century Business. Oxford Capstone Publishing Limited

Lazzari, P. (2018). Issues on Contemporary Management, IBK printing, USA.

Hedstrom, G, Poltorzycki, S, Stroh, P (2017).Sustainable development: The next generation prism 4:5- 20

Holliday,C.(2019).Sustainable growth, the DuPont way. Harvard Business Review September.129- 134

Keating, M.(2017).The Earth Summits Agenda for Change. Geneva: centre for our common future

Price Waterhouse Coopers (2019).Sustainable Monitor (in Dutch: Duurzaamheldsbarmeter), may, measurement 4 . Amsterdam: Price Waterhouse Coopers

Leichenko, R and Silva, J.A (2017).Climate change and Poverty: Vulnerability, Impacts and Alleviation Strategies, WIREs Climate Change doi:10.1002/wcc.287

Kedebe, A.S and Nicholls, R.J (2016)Exposure and Vulnerability to Climate Extremes:

Population and Asset Exposure to Coastal Flooding in Dares Salaam, Tanzania . Regional Environmental Change

Northrop, E. Biru, H, Lima, S, Bouye ,M and Song,R (2016).Examining the Alignment between the intended Nationally Determined Contribution and Sustainable Development Goals, Working Paper, Washington, Dc: World Resources Institute

Orji MG (2017) Impact of Personality Factors on Consumer Buying Behavior of Textile Materials in South Eastern Nigeria (PhD Thesis) Department of Business Administration, Ahmadu Bello University, Zaria, Nigeria,

Orji, M.G, Enobun, P.N (2018). Effect of Work Environment on Teacher Commitment to Duty in Selected Secondary Schools of South Eastern Nigeria, 'Management", (MANA) International Technology and Science Publishers (ITS) United Kingdom. Vol. 1.PP 61- 78.www.itspoa.com/journal/mana

Wilkinson, E, Schipper, L, Simonet.C ,and Kubik, Z. (2016) Climate Change ,Migration and 2030 Agenda for Sustainable Development. Briefing paper. London: Overseas Development Institute

Pedercini,M, Dianati, B and Arquitt, H. (2018).Towards Achieving The SDGs in Ivory Coast: Simulating Pathways to Sustainable Development, March doi;10:1002/sde/1721

Venkataraman, B.(2019).Education for Sustainable development.Environment,51(9),8 - 10 United Nations Framework Convention on Climate Change (2014) "Montreal Climate Change Conference - December, 2005. 